\title{
Effects of changes in micro-weather conditions on structural features, total protein and carbohydrate content in leaves of the Atlantic rain forest tree golden trumpet (Tabebuia chrysotricha)
}

\author{
B. B. Moura ${ }^{a}$, P. H. Almeida ${ }^{a}$, A. G. Balliana ${ }^{a}$, J. Y. G. Cobos ${ }^{a}$, M. Erbano ${ }^{a}$, K. A. do Prado , \\ S. M. Vudala ${ }^{a}$, L. Wosch ${ }^{a}$ and A. B. Pereira-Netto ${ }^{a}$ \\ ${ }^{a}$ Department of Botany - SCB, Universidade Federal do Paraná - UFPR, CP 19031, Curitiba, PR, Brazil \\ *e-mail: bmourabio@gmail.com
}

Received: November 2, 2015 - Accepted: March 22, 2016 - Distributed: August 31, 2017

(With 3 figures)

\begin{abstract}
Golden trumpet, Tabebuia chrysotricha, is a native tree from the Brazilian Atlantic rain forest, with a broad latitudinal distribution. In this study, we investigated the potential effects of short-term changes in micro-weather conditions on structural features, and total protein and carbohydrate content of golden trumpet leaves, using structural and histochemical approaches. Leaves were harvested in four different micro-weather conditions: 1 . Afternoon, after a hot, sunny day; 2. at dawn, after a previously hot, sunny day; 3 . at noon, of a hot, sunny day; and 4. at noon, of a cold, cloudy day. Leaflets exposed to low light irradiance showed flattened chloroplasts, uniformly distributed within the cells, throughout the palisade parenchyma. Conversely, leaflets exposed to high light irradiance presented flattened and rounded chloroplasts, in the upper and lower palisade parenchyma cells, respectively. The strongest protein staining was found for leaves harvested at the coldest period, whereas the weakest protein staining was found for leaves harvested after a hot, sunny day. The largest and most numerous starch grains were found for leaves harvested in the afternoon, after a hot, sunny day. Conversely, the smallest and less numerous starch grains were found for leaves harvested at dawn. Analysis of the data reported herein suggests that the leaflet responses to transient changes in micro-weather conditions are likely to contribute to the golden trumpet successful establishment in the broad latitudinal distribution in which the species is found.
\end{abstract}

Keywords: chloroplast, starch grain, Tabebuia chrysotricha.

\section{Efeito de alterações nas condições micro-climáticas sobre características estruturais, e proteína e carboidratos histoquimicamente marcados, de folhas da árvore da floresta Atlântica ipê amarelo}

\begin{abstract}
Resumo
Ipê amarelo é uma árvore nativa da floresta Atlântica brasileira, encontrada em uma ampla distribuição latitudinal. Neste estudo, nós investigamos os efeitos potenciais de alterações de curto prazo nas condições micro-climáticas sobre características estruturais, proteína e carboidratos histoquimicamente marcados, de folhas de ipê amarelo, usando estratégias de análise estrutural e histoquímicas. As folhas foram marcadas em quatro condições microclimáticas distintas: 1. Tarde, após um dia quente e ensolarado; 2 . Amanhecer, após um dia quente e ensolarado; 3 . Ao meio-dia, de um dia quente e ensolarado; e 4. Ao meio-dia, de um dia frio e nublado. Folíolos expostos à baixa irradiância luminosa apresentaram cloroplastos achatados, uniformemente distribuídos no interior das células, por todo o parênquima paliçádico, enquanto que folíolos expostos à alta irradiância apresentaram cloroplastos achatados e arredondados, nas células superiores e inferiores do parênquima paliçádico, respectivamente. A marcação mais intensa para proteína foi observada para folhas coletadas no momento mais frio de coleta, enquanto que a marcação mais fraca foi observada para folhas coletadas após um dia quente e ensolarado. Os grãos de amido maiores e mais numerosos foram observados em folhas coletadas durante a tarde de dia quente e ensolarado, enquanto que os menores e menos numerosos grãos de amido foram observados em folhas coletadas ao amanhecer.
\end{abstract}

Palavras-chave: cloroplasto, grão de amido, Tabebuia chrysotricha. 


\section{Introduction}

The South American Atlantic forest is one of the 35 world hotspots (http://www.cepf.net/resources/hotspots/ South-America/Pages/Atlantic-Forest.aspx, accessed on October 29th, 2014). Tabebuia chrysotricha (Mart. ex DC.) Standl is a native tree from the Brazilian Atlantic rain forest, commonly known as golden trumpet tree. This species has a broad latitudinal distribution which exposes golden trumpet to a wide range of micro-weather conditions. Located in Southern Brazil, Curitiba city is known to present significantly broad daily changes in both cloudy skies and temperature, which provide an excellent opportunity to study the effects of transient changes in micro-weather conditions on structural features of importance for the environmental adaptability of golden trumpet. Here, we describe the effects of transient changes in the micro-weather conditions on the total protein and starch content, and chloroplast structure and positioning, using a combination of classical structural analysis and histochemical techniques.

\section{Material and Methods}

Three golden trumpet (Tabebuia chrysotricha (Mart. ex DC.) Standl individuals were used in this study. These individuals were grown within the urban perimeter of Curitiba city (Figure 1A-C), on the side of a road access to the BR 277 highway. The specific geographic coordinates for these individuals were $-25^{\circ} 44^{\prime} 9005 \mathrm{~S}$ " and" W -49 ${ }^{\circ} 22^{\prime} 9697$ (individual 1); $-25^{\circ} 45^{\prime} 0388 \mathrm{~S}$ " and" $\mathrm{W}-49^{\circ} 22^{\prime} 9711$ (individual 2); $-25^{\circ} 44^{\prime} 9928 \mathrm{~S}$ " and" W $-49^{\circ} 22$ '9936 (individual 3) (Figure 1B).

Samples from three leaves of each individual of golden trumpet were harvested in four distinct micro-weather conditions (A, B, C and D), between November 9th and November 12th, 2013, as follow: Sample A (Nov. 9th): 6 p.m., after a previously hot, sunny day (air temperature and solar irradiance at the harvest time were $25.0^{\circ} \mathrm{C}$ and $461 \mathrm{~kJ} / \mathrm{m}^{2}$, respectively); Sample B (Nov. 10th): 6 a.m., at dawn, after a previously hot and sunny day (air temperature and solar irradiance at the harvest time were $17.1^{\circ} \mathrm{C}$ and $51 \mathrm{~kJ} / \mathrm{m}^{2}$, respectively); Sample C (Nov. 10th): 12 p.m., of a hot, sunny day (air temperature and solar irradiance at the harvest time were $27.8{ }^{\circ} \mathrm{C}$ and $3759 \mathrm{~kJ} / \mathrm{m}^{2}$ ) and Sample D (Nov. 12th): 12 p.m., of a cold, cloudy day (air temperature and solar irradiance at the harvest time were $22.9^{\circ} \mathrm{C}$ and $3023 \mathrm{~kJ} / \mathrm{m}^{2}$ ) (Figure 2). Micro-weather data were recorded at a weather station (National Institute of Meteorology, Inmet), located approximately $50 \mathrm{~m}$ away from the individuals used in this study (Figure 1B).

For the structural and histochemical analysis, square samples $\left(1 \mathrm{~cm}^{2}\right)$, obtained as shown in Figure 1D, E, were
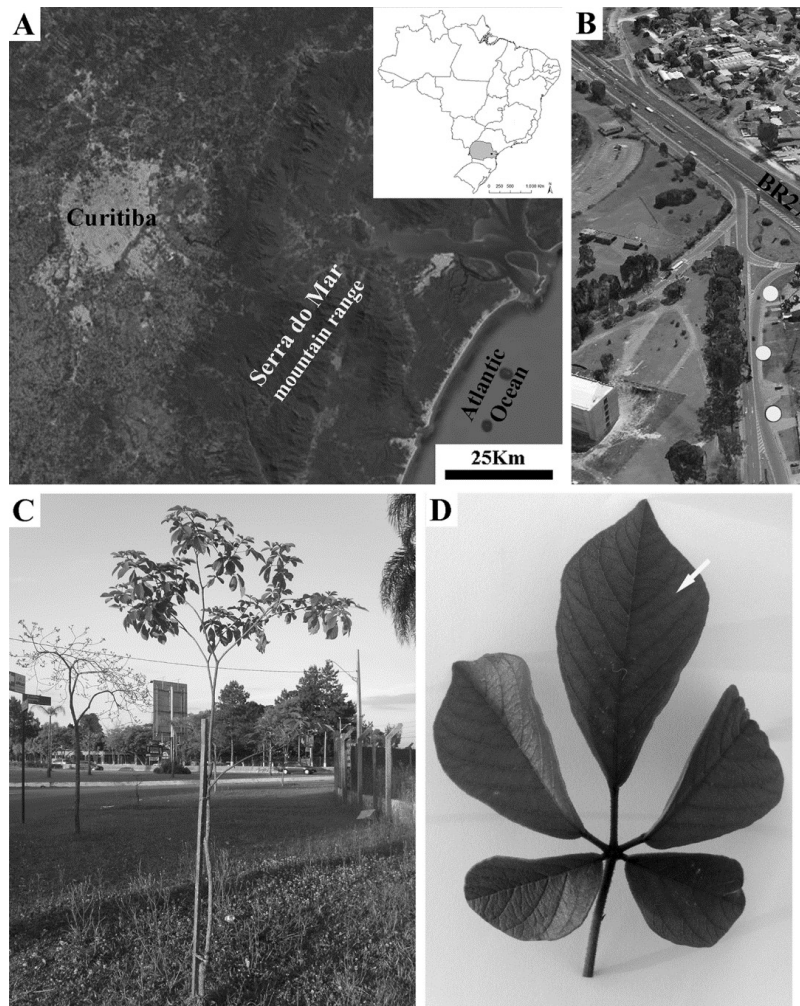

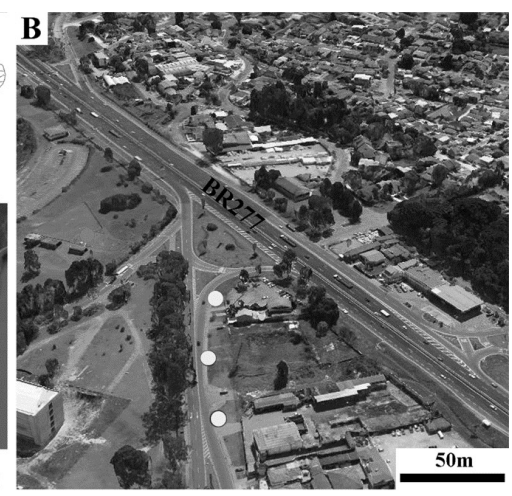

E

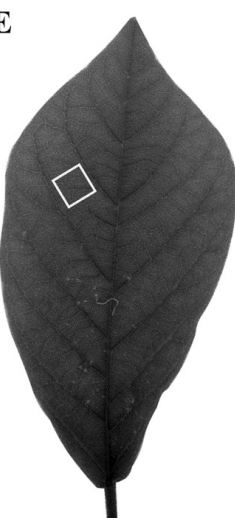

Figure 1. (A) Localization of Curitiba city. The insert shows a map of Brazil, highlighting the Paraná State (in gray) and Curitiba city; (B) Sampling sites (O) near BR277 highway; (C) Golden trumpet tree at the sampling location; (D) Detail of the leaf, with the arrow pointing to the sampled leaflet; (E) Sampled leaflet showing the sampled area (square). Source of figures (A) and (B): Google Maps (2013). 


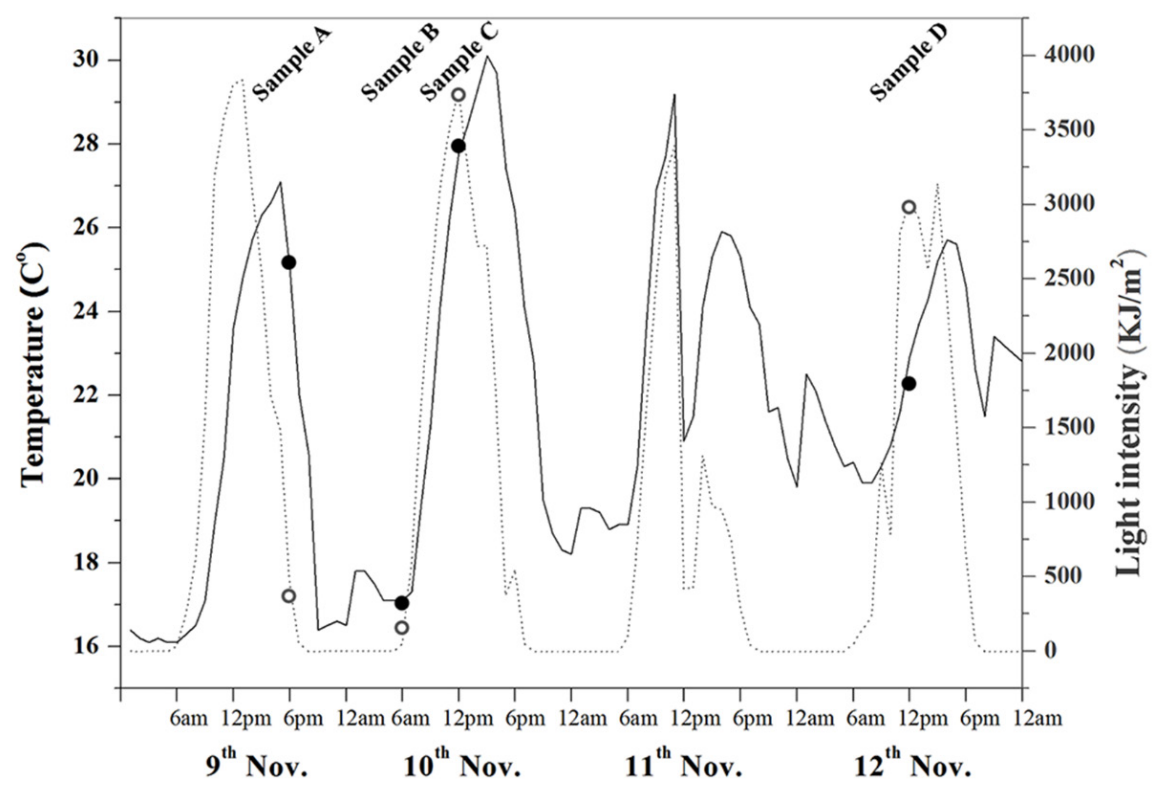

Figure 2. Daily changes in air temperature (black line) and light intensity (global solar radiation, dotted line) recorded at a weather station located approximately $50 \mathrm{~m}$ away from the harvest site, during the sampling period. Black circles and open circles indicate air temperature and light intensity, respectively, at the sampling time. Sample A - Nov. 9 th at 6 p.m. Sample B - Nov. 10th at 6 a.m. Sample C - Nov. 10th at 12 p.m. Sample D - Nov. 12th at 12 p.m. Source: INMET (2013).

cut with a razor blade, and immediately fixed in $2.5 \%(\mathrm{v} / \mathrm{v})$ glutaraldehyde, buffered at $\mathrm{pH} 7.0$ with $0.067 \mathrm{M}$ Soerensen phosphate buffer. Then, the samples were vacuum infiltrated $(65 \mathrm{kPa})$, for $30 \mathrm{~min}$. The observations were performed on five $2 \mu \mathrm{m}$ semi-thin cuttings, of each sample, obtained after samples were embedded in hidroxyethyl methacrylate (Leica Microsystems, Wetzlar, Germany). The cutting was carried out using an ultramicrotome LEICA EM UC6 (Leica Microsystems, Wetzlar, Germany). The samples were stained using staining procedures specific for the desired attributes, as follows: Toluidin Blue (Feder and O'Brien, 1968) for the structural analysis; Coomassie Blue (Wetzel et al., 1989) for total protein content; and Periodic Acid Schiff(PAS, Gahan, 1984) for polyssacharides, acidic carbohydrates and neutral mucoproteins. Thereafter, the slides were mounted in DePex medium (Sigma-Aldrich, United Kingdom). For the structural analysis and generation of digital images, an Olympus compound microscope (BX41TF, Tokyo, Japan) equipped with an analySIS getIT software (Olympus Soft Imaging Solution, Australia) was used.

\section{Results}

Structural analysis of leaflets exposed to low light irradiance (samples A, B and D) showed flattened chloroplasts, uniformly distributed within the cells, throughout the palisade parenchyma (Figure 3A, B, D). Moreover, the vacuoles volume seemed to be similar in cells located in both the upper and lower layers of the palisade parenchyma. However, leaflets exposed to high light irradiance (sample C) showed that the upper palisade parenchyma cells presented flattened chloroplasts, while the lower palisade parenchyma cells presented rounded chloroplasts (Figure 3C). Differently from what was found for the leaflet exposed to low light irradiance, in leaflets exposed to high light irradiance, the chloroplast, regardless if they were rounded or flattened, were not uniformly distributed within the palisade parenchyma cells; instead, chloroplast were preferentially located in the bottom of the cells. These rounded chloroplasts presented a larger number and size of starch grains, especially near the paravenal parenchyma, when compared to the flattened chloroplasts. Also, in leaflets exposed to high light irradiance, the upper cells of the palisade parenchyma presented larger vacuoles, occupying a larger amount of the symplast, when compared to the lower cells of the palisade parenchyma (Figure 3C).

Samples harvested at 6 p.m., after a hot, sunny day (sample A, Figure 3E) presented the weakest protein staining, when compared to the other three samples. Conversely, staining for protein was more intense in samples harvested at 6 a.m., at dawn, after a high temperature night (average of $20.4{ }^{\circ} \mathrm{C}$, ranging from 17.1 to $27.1^{\circ} \mathrm{C}$ ) and a previously hot and sunny day (sample B, Figure 3F). Samples harvested at 12 p.m. of a hot, sunny day (sample C, Figure 3G) presented less intense protein staining, not uniformly distributed, i.e., protein staining was less intense near the paravenal parenchyma and more intense near the adaxial epidermis, when compared to the samples harvested at $12 \mathrm{p} . \mathrm{m}$. of a cold, cloudy day (sample D, Figure 3H). Sample D presented weaker protein staining, with no evident gradient, 


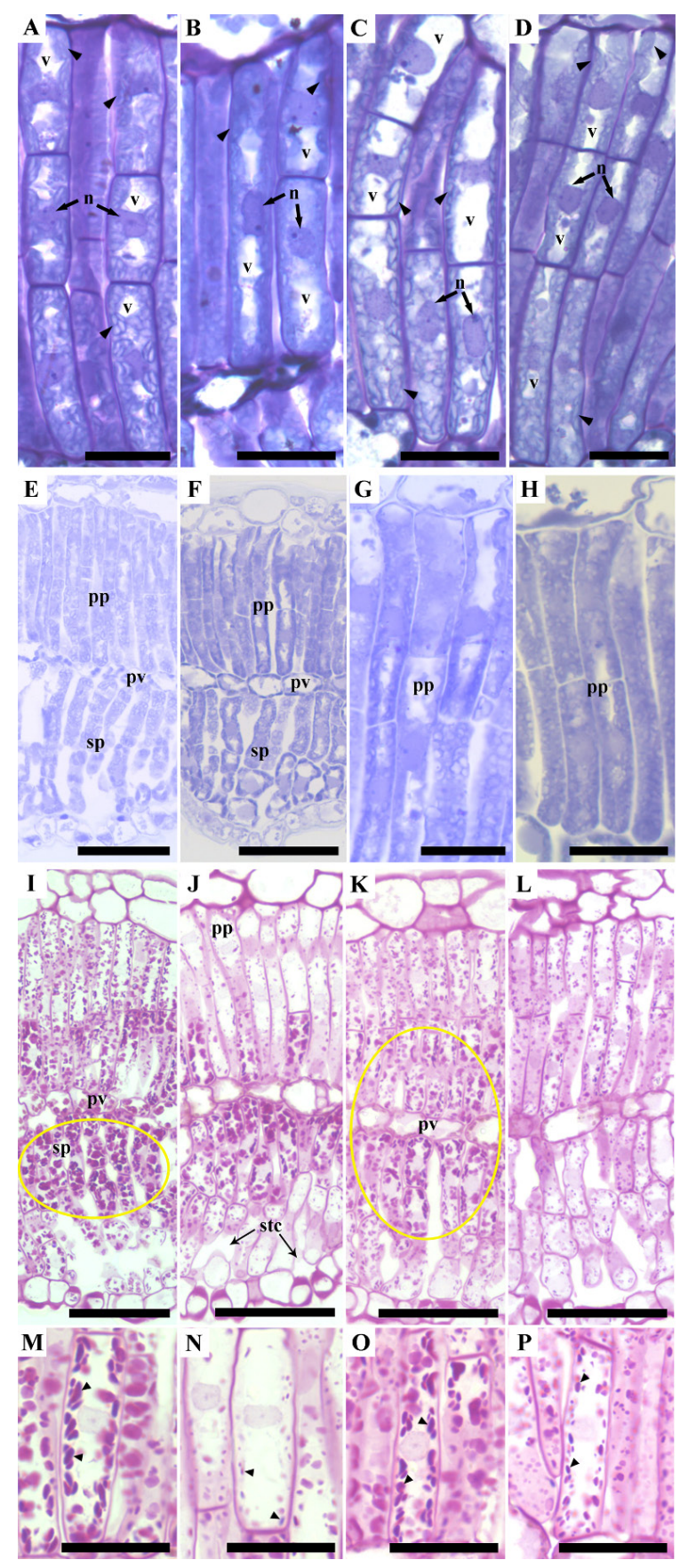

Figure 3. Cross section of Golden trumpet leaflets, (A-D) samples stained with Toluidine Blue, highlighting chloroplast (arrow heads) vacuoles (v) and nucleus (n). (A) Sample A; (B) Sample B; (C) Sample C; (D) Sample D. Arrow heads indicate chloroplasts homogenously distributed throughout the palisade parenchyma in figures (A), (B) and (D) and preferentially distributed closer to the paravenal parenchyma in figure (C); (E-H) samples stained with Coomassie blue highlighting palisade parenchyma (pp), spongy parenchyma (sp) and paravenal parenchyma (pv). (E) Sample A, with weak protein stain; (F) Sample B, with strong protein stain; (G) Sample C, with protein gradient stain within the palisade parenchyma tissue; (H) Sample D, without protein gradient stain; (I-P) samples stained with PARS, highlighting palisade parenchyma (pp), spongy parenchyma (sp) and paravenal parenchyma (pv), substomatal chamber (stc) and starch graisn (arrow heads) (I and M) Sample A. (I) Large starch grains in sp near pv (elipse) and (M) detail of large starch grains inside the cells; (J and N) Sample B. (J) Small starch grains near the upper pp layers and stc and (N) detail of small starch grains inside the cells; (K and O) Sample C. (K) Starch grains distributed near pv (elipse) and (O) detail of large starch grains inside the cells; (L and P) Sample D. (L) Small starch grains homogeneously distributes through the mesophyll and (P) detail of smaller starch inside the cell. A-D, G, H, M-P, bars $=20 \mu \mathrm{m}$; E, F, M-P, bars $=50 \mu \mathrm{m}$. 
i.e., the protein staining was homogeneously distributed throughout the mesophyll.

The periodic acid schiff reagent (PAS) labels for polyssacharides, acidic carbohydrates and neutral mucoproteins. Since starch is the major non-structural polyssacharide in health plant cells, we assumed that PAS staining outside cell walls was due to the presence of starch. The largest number and size of starch grains were found for samples harvested at 6 p.m., after a hot, sunny day (sample A), in the spongy parenchyma, especially near the paravenal parenchyma (Figure 3I, M). Conversely, the smallest number and size of starch grains, were observed for samples harvested at 6 a.m. (sample B), especially in the upper palisade parenchyma, and cells near the substomatal chamber (Figure 3J, N). Among the samples harvested at noon, leaves harvested in a sunny, hot day (sample C), presented larger starch grains (Figure 3K, O), when compared to leaves harvested at noon, in a cloudy, cold day (sample D, Figure 3L, P). In addition, starch grains in sample $\mathrm{C}$ were found to be preferentially distributed closer to the paravenal parenchyma (Figure 3K), while starch grains in sample D were homogeneously distributed throughout the mesophyll (Figure 3L).

\section{Discussion}

\subsection{Structural analysis}

Frequent light irradiance fluctuations are known to induce plants to create strategies for adaptation to optimize the photosynthetic efficiency and resource acquisition (Anderson et al., 1973, 1988; Anderson, 1999). The irregular distribution of chloroplasts previously reported for leaves exposed to high light irradiance is thought to be part of a defense mechanism against the excessive light irradiance that triggers the photosynthetic photoinhibition process. Golden trumpet is considered to be able to adapt to environments with broad shifts in solar radiation levels (Soares, 2012) and data in this report indicate that this adaptability might be, at least partially, due to the changes in chloroplast distribution found in this study for leaves exposed to different light irradiance levels.

The vacuoles play various roles in plant cells, such as generation of cell turgor (reviewed in Newell et al., 1998). However, relatively little is known about the formation and growth of vacuoles in higher plants. In this study, the upper cells of the palisade parenchyma of leaflets exposed to high light irradiance presented larger vacuoles, compared to the lower cells. However, the importance of that for the adaptability of golden trumpet to different environments remain unclear.

\subsection{Protein content}

The rate of photosynthesis depends largely on the amount and activity of Ribulose bisphosphate carboxylase/ oxygenase (Rubisco) (Lorimer, 1981). Rubisco, the first and key enzyme in the Calvin cycle, catalyzes the incorporation of carbon dioxide to ribulose-1,5-bisphosphate. Large amounts of Rubisco are required to catalyze carbon fixation at high rates (reviwed in Spreitzer and Salvucci, 2002). Since Rubisco is responsible for up to half of the soluble protein in leaves of C3 plants (Ellis, 1979), the presumption that Rubisco is significantly accountable for the protein staining found in this study is reasonable.

In this study, protein staining was more intense in leaves harvested in a cold, low light irradiance day (day 12th), when compared to leaves harvested in a warm $\left(\approx 28^{\circ} \mathrm{C}\right.$, at the harvest time), high light irradiance day (10th). Low daytime temperature may inhibit photosynthesis (Pyl et al., 2012), once it can significantly affect Rubisco content, whereas, changes in light irradiance have been shown not to significantly affect it (Yang et al., 2011). Although exposure of plants such as rice to cold temperatures has been shown to reduce Rubisco synthesis (Hahn and Walbot, 1989), in plant shrub as Aucuba japonica, Rubisco content is increased from summer to the highest values in winter and/or early spring (Muller et al., 2011). Thus, since predawn temperature on day 10th (sample C) was lower, compared to predawn temperature on day 12th (sample D), therefore, the potentially reduced Rubisco synthesis during the first hours of day 10th might be, at least in part, responsible for the weaker protein staining found for day 10th, compared to day 12 th.

\subsection{Polysaccharides content}

The largest and most numerous starch grains were found in this study for samples harvested at 6 p.m. after a hot, sunny day, likely reflecting the stimulatory effect of the combination of high temperature and high light irradiance on the leaf photosynthetic capacity. Conversely, the smallest and less numerous starch grains were found for samples harvested at 6 a.m., likely reflecting starch degradation during the night. Starch, the major storage carbohydrate found in higher plants (Wang et al., 2013), accumulates during the light period and is remobilized during the night in leaves of $\mathrm{C}_{3}$ and $\mathrm{C}_{4}$ plants, the so called transitory starch degradation, for example to support respiration in the dark (Geiger and Servaites, 1994; Wang et al., 2013). The amount of starch accumulated during the day and degraded during the night is coordinated by an internal circadian clock (Scialdone et al., 2013). Since AGPase play a major regulatory role in starch biosynthesis (Geigenberger, 2011), not surprisingly, much of the research on the regulation of starch metabolism has focused on the regulation of AGPase. The expression of AGPase is enhanced by sugars, which may allow starch accumulation to respond to changes in environmental constraints (reviewed in Geigenberger, 2011). Two different mechanisms act on AGPase in order to turn on starch synthesis during the light period and off during the dark. First, light incidence on the chloroplasts leads to fast redox activation of AGPase, which is fully reversed in the dark (Hendriks et al., 2003). This redox regulation likely helps to coordinate starch synthesis and breakdown during the light/dark cycle (Stitt et al., 2010). Second, allosteric regulation of AGPase provides an additional mechanism for light/dark modulation of starch biosynthesis. Allosteric regulation combined with redox 
regulation act synergistically on AGPase to stimulate starch synthesis during the light and full inactivation during the dark (Geigenberger, 2011). Starch accumulation pattern found in this work indicate that effective light-induced allosteric regulation combined with redox regulation of golden trumpet AGPase might contribute significantly for the adaptability of this Atlantic rain forest tree to latitudinal gradient.

In leaves, starch degradation begins with the phosphorylation of glucose residues of amylopectin by glucan-water dikinase (GWD) (Grennan, 2006). Even though a considerable amount of information on the regulation of enzymes involved in starch synthesis is available, much less is known about the regulation of starch degradation. For example, transcript levels of many enzymes involved in starch degradation were shown to fall progressively throughout the dark period and increased during the latter part of the light period (Grennan, 2006). A reduction in number and size of starch grains, an indicator of degradation of the transitory starch, was evident in this study in samples harvested at 6 a.m. This reduction in transitory starch occurred mostly in the upper layers of the palisade parenchyma and also inside the cells surrounding the substomatal chamber. The reason(s) why the reduction in transitory starch occurred mostly in the upper layers of the palisade parenchyma is(are) not clear. However, the reduction in transitory starch occurred in the cells surrounding the substomatal chamber might be due to an eventually higher respiration rate found in these cells, as a consequence of a presumed higher inward flux of oxygen and a higher outward flux of $\mathrm{CO}_{2}$, due to the location of these cells at the vicinity of the stomata pore

Larger starch grains and a larger number of starch grains were found for samples harvested at 12 a.m. of a hot, sunny day (sample C), compared to samples harvested at 12 a.m. of a cold and cloudy day (sample D). Conversely, protein staining was weaker on sample $C$, when compared to sample D. In fact, regardless the harvest time, an inverse relationship between protein content and starch content was observed throughout this study. This inverse relationship, however, is not a complete surprise once starch metabolized to glucose in the dark period, is considered to be able to play a role in sugar signaling decreasing the expression photosynthetic genes (Cheng et al., 1998). In addition, Rubisco activity during photosynthesis is regulated by the Rubisco activase (Bayramov and Guliyev, 2014), and Rubisco activase is thought to be a key regulation point for the biochemical reactions of photosynthesis (Portis Junior, 2003). Rubisco activase is regulated by the ferredoxin/thioredoxin system and ferredoxin then can donate electrons to ferredoxin:thioredoxin reductase which then reduces the thioredoxins. Thioredoxins then reduce and thereby activate or inactivate Rubisco activase (reviewed in Zhang et al., 2001). Furthermore, Rubiso activase activity is enhanced by increased temperature, up to $42{ }^{\circ} \mathrm{C}$ in tobacco recombinant protein (Crafts-Brandner and Salvucci, 2000). Thus, the presence of larger starch grains in sample D might be due to a high light irradiance/high temperature-induced enhancement of Rubisco activase activity and consequently higher Rubisco activity, on day 12 th (sample C), compared to day 10th (sample D).

Data presented in this study demonstrate that transient changes in micro-weather conditions significantly change the chloroplast position and shape, amount of protein, and pattern of starch accumulation/degradation in leaves of golden trumpet. Light irradiance and temperature-driven changes in the pattern of protein and starch accumulation/ degradation found in this study indicate that adaptability of golden trumpet to different environmental light and temperature conditions might be dependent on efficient adaptability of the photosynthetic apparatus to changes in light and thermal environment. This adaptability is likely to contributes, at least partially, for its vast latitudinal distribution throughout the Atlantic rain forest, as an important species to be used in disturbed ecosystem restoration (Baylão Junior et al., 2013) and in the successful establishment of this species in urban arborization (Jochner et al., 2013) in South America.

\section{Acknowledgements}

The authors thank CNPq-Brazil for financial support.

\section{References}

ANDERSON, J.M., 1999. Insights into the consequences of grana stacking of thylakoid membranes in vascular plants: a personal perspective. Australian Journal of Plant Physiology, vol. 26, no. 7, pp. 626-639. http://dx.doi.org/10.1071/PP99070.

ANDERSON, J.M., CHOW, W.S. and GOODCHILD, D.J., 1988. Thylakoid membrane organization in sun/shade acclimation. Australian Journal of Plant Physiology, vol. 15, no. 2, pp. 11-26. http://dx.doi.org/10.1071/PP9880011.

ANDERSON, J.M., GOODCHILD, D.J. and BOARDMAN, N.K., 1973. Composition of photosystems and chloroplast structure in extreme shade plants. Biochimica et Biophysica Acta: Bioenergetics, vol. 325, no. 3, pp. 573-585. PMid:4778294. http:// dx.doi.org/10.1016/0005-2728(73)90217-X.

BAYLÃO JUNIOR, H.F., VALCARCEL, R. and NETTESHEIM, F.C., 2013. Fatores do meio físico associados ao estabelecimento de espécies rústicas em ecossistemas perturbados na Mata Atlântica, Piraí, RJ - Brasil. Ciência Florestal, vol. 23, no. 3, pp. 305-315. http://dx.doi.org/10.5902/1980509810542.

BAYRAMOV, S. and GULIYEV, N., 2014. Changes in Rubisco activase gene expression and polypeptide content in Brachypodium distachyon. Plant Physiology and Biochemistry, vol. 81, pp. 61-66. PMid:24521715. http://dx.doi.org/10.1016/j.plaphy.2014.01.013.

CHENG, S.H., MOORE, B.D. and SEEMANN, J.R., 1998. Effects of short- and long-term elevated $\mathrm{CO}_{2}$ on the expression of Ribulose-1,5-bisphosphate carboxylase/oxygenase genes and carbohydrate accumulation in leaves of Arabidopsis thaliana. Plant Physiology, vol. 116, no. 2, pp. 715-723. PMid:9489018. http://dx.doi.org/10.1104/pp.116.2.715.

CRAFTS-BRANDNER, S.J. and SALVUCCI, M.E., 2000. Rubisco activase constrains the photosynthetic potential of leaves at high temperature and $\mathrm{CO}_{2}$. PNAS. Proceedings of the National Academy of Sciences of the United States of America, 
vol. 97, no. 24, pp. 13430-13435. PMid:11069297. http://dx.doi. org/10.1073/pnas.230451497.

ELLIS, J.R., 1979. The most abundant protein in the world. Trends in Biochemical Sciences, vol. 4, no. 11, pp. 241-244. http://dx.doi. org/10.1016/0968-0004(79)90212-3.

FEDER, N. and O'BRIEN, T.P., 1968. Plant microtechnique: some principles and new methods. American Journal of Botany, vol. 55, no. 1, pp. 123-142. http://dx.doi.org/10.2307/2440500.

GAHAN, P.B., 1984. Plant histochemistry and cytochemistry: an introduction. London: Academic Press.

GEIGENBERGER, P., 2011. Regulation of starch biosynthesis in response to a fluctuating Environment. Plant Physiology, vol. 155, no. 4, pp. 1566-1577. PMid:21378102. http://dx.doi. org/10.1104/pp.110.170399.

GEIGER, D.R. and SERVAITES, J.C., 1994. Diurnal regulation of photosynthetic carbon metabolism in $\mathrm{C}_{3}$ plants. Annual Review of Plant Physiology and Plant Molecular Biology, vol. 45, no. 1, pp. 235-256. http://dx.doi.org/10.1146/annurev.pp.45.060194.001315.

GOOGLE MAPS, 2013. [accessed 4 December 2013]. Available from: https://www.google.com.br/maps/place/Curitiba,+State+of+Paraná

GRENNAN, A.K., 2006. Regulation of starch metabolism in Arabidopsis leaves. Plant Physiology, vol. 142, no. 4, pp. 13431345. PMid:17151136. http://dx.doi.org/10.1104/pp.104.900209.

HAHN, M. and WALBOT, V., 1989. Effects of cold-treatment on protein synthesis and mRNA levels in rice leaves. Plant Physiology, vol. 101, no. 3, pp. 523-533. PMid:16667159.

HENDRIKS, J.H.M., KOLBE, A., GIBON, Y., STITT, M. and GEIGENBERGER, P., 2003. ADPglucose pyrophosphorylase is activated by posttranslational redox modification in response to light and to sugars in leaves of Arabidopsis and other plant species. Plant Physiology, vol. 133, no. 2, pp. 838-849. PMid: 12972664. http://dx.doi.org/10.1104/pp.103.024513.

INSTITUTO NACIONAL DE METEOROLOGIA - INMET, 2013. [accessed 15 November 2013]. Available from: www. inmet.gov.br/sonabra/pg_dspDadosCodigo.php?QTgwNw==

JOCHNER, S., ALVES-EIGENHEER, M., MENZEL, A. and MORELLATO, L.P.C., 2013. Using phenology to assess urban heat islands in tropical and temperate regions. International Journal of Climatology, vol. 33, no. 15, pp. 3141-3151. http:// dx.doi.org/10.1002/joc.3651.

LORIMER, G.H., 1981. The carboxylation and the oxygenation of ribulose-1,5-bisphosphate: the primary event in photosynthesis and photorespiration. Annual Review of Plant Physiology, vol. 32, no. 1, pp. 349-383. http://dx.doi.org/10.1146/annurev. pp.32.060181.002025.

MULLER, O., HIROSE, T., WERGER, M.J.A. and HIKOSAKA, K., 2011. Optimal use of leaf nitrogen explains seasonal changes in leaf nitrogen content of an understorey evergreen shrub. Annals of Botany, vol. 108, no. 3, pp. 529-536. PMid:21757476. http:// dx.doi.org/10.1093/aob/mcr167.
NEWELL, J.M., LEIGH, R.A. and HALL, J.L., 1998. Vacuole development in cultured evacuolated oat mesophyll protoplasts. Journal of Experimental Botany, vol. 49, no. 322, pp. 817-827. http://dx.doi.org/10.1093/jxb/49.322.817.

PORTIS JUNIOR, A.R., 2003. Rubisco activase: Rubisco's catalytic chaperone. Photosynthesis Research, vol. 75, no. 1, pp. 11-27. PMid:16245090. http://dx.doi.org/10.1023/A:1022458108678.

PYL, E.-T., PIQUES, M., IVAKOV, A., SCHULZE, W., ISHIHARA, H., STITT, M. and SULPICE, R., 2012. Metabolism and growth in Arabidopsis depend on the daytime temperature but are temperature-compensated against cool nights. The Plant Cell, vol. 24, no. 6, pp. 2443-2469. PMid:22739829. http://dx.doi. org/10.1105/tpc.112.097188.

SCIALDONE, A., MUGFORD, S.T., FEIKE, D., SKEFFINGTON, A., BORRILL, P., GRAF, A., SMITH, A.M. and HOWARD, M., 2013. Arabidopsis plants perform arithmetic division to prevent starvation at night. eLife, vol. 2, pp. 1-24. PMid:23805380. http:// dx.doi.org/10.7554/eLife.00669.

SOARES, M.G., 2012. Plasticidade fenotipica de plantas jovens de Handroanthus chrysotrichus (Mart. ex DC.) Mattos (Bignoniaceae) em resposta a radiação solar. Vitória: Universidade Federal do Espírito Santo. Masters Dissertation.

SPREITZER, R.J. and SALVUCCI, M., 2002. RUBISCO: Structure, regulatory interactions, and possibilities for a better enzyme. Annual Review of Plant Biology, vol. 53, no. 1, pp. 449-475. PMid:12221984. http://dx.doi.org/10.1146/annurev. arplant.53.100301.135233.

STITT, M., LUNN, J. and USADEL, B., 2010. Arabidopsis and primary photosynthetic metabolism: more than the icing on the cake. The Plant Journal, vol. 61, no. 6, pp. 1067-1091. PMid:20409279. http://dx.doi.org/10.1111/j.1365-313X.2010.04142.x.

WANG, Y., YU, B., ZHAO, J., GUO, J., LI, Y., HAN, S., HUANG, L., DU, Y., HONG, Y., TANG, D. and LIU, Y., 2013. Autophagy contributes to leaf starch degradation. The Plant Cell, vol. 25, no. 4, pp. 1383-1399. PMid:23564204. http://dx.doi.org/10.1105/ tpc.112.108993.

WETZEL, S.C., DEMMERS, J. and GREENWOOD, S., 1989. Seasonally fluctuating bark proteins are a potential form of nitrogen storage in three temperature hardwoods. Planta, vol. 178, no. 3, pp. 275-281. PMid:24212893. http://dx.doi.org/10.1007/BF00391854.

YANG, Q., HE, H., LI, H., TIAN, H., ZHANG, J., ZHAI, L., CHEN, J., WU, H., YI, G., HE, Z. and PENG, X., 2011. NOA1 functions in a temperature-dependent manner to regulate chlorophyll biosynthesis and Rubisco formation in rice. PLoS One, vol. 6, no. 5, pp. e20015. PMid:21625436. http://dx.doi.org/10.1371/ journal.pone.0020015.

ZHANG, N., SCHÜRMANN, P. and PORTIS JUNIOR, A.R., 2001. Characterization of the regulatory function of the 46-kDa isoform of Rubisco activase from Arabidopsis. Photosynthesis Research, vol. 68, no. 1, pp. 29-37. PMid:16228326. http://dx.doi. org/10.1023/A:1011845506196. 